\title{
HUBUNGAN POLA MAKAN DENGAN KEJADIAN SINDROMA DISPEPSIA FUNGSIONAL PADA REMAJA DI MADRASAH ALIYAH NEGERI MODEL MANADO
}

\author{
Susilawati \\ Stella Palar \\ Bradley J.Waleleng \\ Kandidat Skripsi Fakultas Kedokteran Universitas Sam Ratulangi Manado \\ Bagian Interna Fakultas Kedokteran Universitas Sam Ratulangi Manado \\ Email: susilawati.09_128@yahoo.com
}

\begin{abstract}
Susilawati., 2013. The relation of eating patterns with Genesis Functional Dyspepsia Syndrome in Adolescents in MAN Model Manado. Thesis, Medical Faculty of the University of Sam Ratulangi Manado. Counselor dr. B.J.Waleleng, SpPD-KGEH, Advisor dr. Stella Palar, SpPD-KGH.Dyspepsia syndrome is collection of symptoms of pain or discomfort in the upper abdomen that episodic. It is very common among the public, especially in adolescents. Syndrome dyspepsia have dysfunctional and organic.Dyspepsia syndrome is caused by various factors, one of which is irregular eating patterns. The aims of this study is to determine the extent of the relationship between diet and incidence of dyspepsia syndrome in young students MAN Model Manado Research is descriptive study conducted analytic survey by using questionnaires. Study sample 50 adolescents aged 16-17 years who attend school in MAN Model Manado. Purposive sampling method. The results showed irregular eating frequency $48 \%$, and spicy foods much $70 \%$. Incidence of dyspepsia syndrome the overall sample $96 \%$. And the analysis demonstrated an association with eating syndrome incidence of dyspepsia in MAN Model Manado.Adolescents are expected to pay attention to their eat patterns and be more disciplined in managing the daily feeding schedule day.
\end{abstract}

Keywords: diet, dyspepsia syndrome, adolescents

Abstrak : Susilawati. 2013. Hubungan Pola Makan dengan Kejadian Sindroma Dispepsia Fungsional pada Remaja di Madrasah Aliyah Negeri Model Manado. Skripsi, Fakultas kedokteran Universitas Sam Ratulangi Manado. Pembimbing dr. B.J.Waleleng, SpPDKGEH, Pembimbing dr.Stella Palar, SpPD-KGH.Sindroma dispepsia adalah kumpulan gejala nyeri atau rasa tidak enak di abdomen atas yang episodik. Hal ini sangat umum di kalangan masyarakat khususnya pada remaja. Sindroma dispepsia mempunyai kelainanan fungsional dan organik.Sindroma dispepsia disebabkan oleh berbagai faktor, salah satunya adalah pola makan yang tidak teratur. Pada penelitian ini bertujuan untuk mengetahui sejauh mana hubungan antara pola makan dengan kejadian sindroma dispepsia pada siswa remaja di MAN Model ManadoPenelitian deskriptifanalitik dengan survei menggunakan kuisioner.Sampelpenelitian 50 orang remaja yang berusia $16-17$ tahun yang bersekolah di Madrasah Aliyahnegeri Model Manado. Sampel diambil dengan metode purposive sampling. Hasil penelitian menunjukkan frekuensi makan yang tidak teratur $48 \%$, dan mengkonsums 
imakanan pedas sebanyak 70\%. Angka kejadian sindroma dyspepsia dari keseluruhan sampel 96\%. Hasil analisis menunjukkan terdapat hubungan pol amakan dengan kejadian sindroma dyspepsia pada remaja di MAN Model Manado. Diharapkan remaja dapat memperhatikan pola makannya dan lebih disiplin dalam mengatur jadwal makan sehari - hari.

Kata kunci: pola makan, sindroma dispepsia, remaja

\section{Pendahuluan}

\section{A. Latar Belakang}

Masa remaja merupakan suatu periode dari perkembangan manusia.Di sebagian besar masyarakat dan budaya masa remaja pada umumnya di mulai pada usia 10-13 tahun dan berakhir pada usia 18-22 tahun.Menurut soetjiningsih(2004) masa remaja merupakan masa peralihan antara masa anak- anak yang di mulai saat terjadinya kematangan seksual yaitu antara 11 atau 12 tahun sampai dengan tahun,yaitu masa menjelang dewasa muda. ${ }^{1}$

World Health Organization ( WHO ) menetapkan batasan usia remaja dalam 2 bagian yaitu remaja awal 10-12 tahun dan remaja akhir 15-20 tahun. ${ }^{2}$ Sedangkan dari segi program pelayanan, definisi remaja yang digunakan oleh departemen kesehatan adalah mereka yang berusia 10 sampai 19 tahun dan belum kawin. Sementara itu, menurut direktorat remaja dan perlindungan hak reproduksi batasan usia remaja adalah 10 sampai 21 tahun. ${ }^{3}$

Populasi remaja di indonesiaberjumlah $21 \%$ dari total penduduk, dengan jumlah \pm 44 juta jiwa. Masa remaja ditandai oleh perubahan yang besar, Hall (1989) dalam Papalia dan Olds (1998) menyebut masa ini sebagai periode "storm and stress", yaitu suatu masa dimana ketegangan emosi meningkat sebagai akibat perubahan fisik dan kelenjar. Pola makan yang tidak teratur dan gaya hidup yang cenderung mudah terbawa arus umumnya menjadi masalah yang timbul pada remaja.

Perkembangan teknologi, industri, dan era keterbukaan informasi saat ini membawa konsekuensi terhadap perubahan gaya hidup, kondisi lingkungan, dan perilaku masyarakat,termasuk remaja. Kecenderungan mengkonsumsi makanan cepat saji dan makanan instan, gaya hidup menjadi lebih sedentary, stres, dan polusi telah menjadi bagian dari kehidupan sehari-hari. Gaya hidup dan kebiasaan makan yang salah akan secara langsung akan mempengaruhi organ-organ pencernaan dan menjadi pencetus penyakit pencernaan. Salah satu penyakit pencernaan yang sering dikeluhkan adalah gangguan lambung. Lambung adalah reservoir pertama makanan dalam tubuh dan di organ tersebut makanan melalui proses pencernaan dan penyerapan sebagian zat gizi. Gangguan lambung berupa ketidaknyamanan pada perut bagian atas atau dikenal sebagai sindrom dispepsia. Dispepsia dapat terjadi akibat kelainan organik maupun fungsional. Gangguan organik yang umum terjadi pada lambung antara lain gastritis dan tukak peptik (dikenal dengan sakit maag), esophageal reflux disease, penyakit kandung empedu, gangguan hati, dan patologi lainnya

Prevalensi dispepsia sendiri secara global bervariasi antara 7-45\% tergantung pada definisi yang digunakan dan lokasi geografis. Prevalensi dispepsia di Amerika Serikat sebesar 23-25,8\%, di India 30,4\%, New Zealand 34,2\%, Hongkong 18,4\%, dan Inggris 38$41 \%$. Di Indonesia, dispepsia menempati urutan ke-15 dari 50 penyakit yang dengan pasien rawat inap terbanyak (Depkes 2006). Laporan rawat jalan di RSUP dr. Sardjito Yogyakarta menjelaskan bahwa pasien yang datang dengan keluhan dispepsia mencapai $40 \%$ kasus per tahun. $^{4}$

\section{B.Rumusan Masalah}


Berdasarkan latar belakang tersebut,maka didapatkan masalah yaitu apakah ada hubungan pola makan dengan kejadian sindroma dispepsia pada remaja di Madrasah Aliyah Negeri Model Manado.

\section{C.Tujuan Penelitian}

Tujuan umum

Untuk mengetahui sejauh mana hubungan antara pola makan dengan kejadian sindroma dispepsia pada siswa remaja di Madrasah Aliyah Negeri Model Manado.

\section{Tujuan khusus}

1. Mengetahui hubungan pola makan dengan kejadian sindroma dispepsia pada remaja di Madrasah Aliyah Negeri Model Manado.

2. Mengetahui jenis makanan yang mempengaruhi terjadinya sindroma dispepsia pada remaja di Madrasah Aliyah Negeri Model Manado.

\section{Manfaat Penelitian}

Hasil penelitian ini diharapkan dapat memberikan manfaat :

1. Untuk memperluas pengetahuan tentang sindroma dispepsia

2. Dapat mengetahui pencegahan terjadinya dispepsia dan cara mengatur pola makan yang baik.

\section{E. Hipotesis}

Ada hubungan antara pola makan dengan kejadian sindroma dispepsia pada remaja di MAN Model Manado .

\section{METODOLOGI PENELITIAN}

Jenis Penilitian yang dilakukan adalah penelitian deskriptif analitik dengan cara survei menggunakan kuisioner.Lokasi Penelitian di Madrasah Aliyah Negeri Model Manado di Tuminting.Waktu Pelaksanaan Penelitian dilakukan dalam waktu 2 bulan yaitu dari bulan oktober - desember 2012.Populasi dan Sampel adalah Pelajar di MAN Model Manado kelas 3 dengan umur berkisar 16-17 tahun. Yang berjumlah 50 siswa.Jumlah keseluruhan siswa kelas 3Madrasah Aliyah Negeri Model Manado adalah 278 siswa yang terdaftar sampai bulan November 2012 Sampel penelitian yaitu Besar sampel untuk survei ditentukan dengan cara Purposive sampling yaitu peneliti menentukan sendiri sampel yang diambil.

\section{A. Variable Penelitian}

1. Karakteristik Koresponden ( umur, jenis kelamin, IMT,tinggal dengan siapa)

2. Gambaran pola makan (Pola makan, jenis makanan, kebiasaan responden).

\section{B. Definisi Operasional}

1. Karakteristik Responden : Kriteria yang akan diukur dari remaja meliputi usia (16-17 tahun), jenis kelamin (laki-laki dan perempuan), indeks massa tubuh (Underweight $\leq 18$, normal 18,5-25, overweight $\geq 25$ ), tempat tinggal (orang tua, saudara/kerabat, asrama, dan kost).

2. Sindroma Dispepsia : Kumpulan gejala yang terdiri atas nyeri ulu hati, mual, kembung, muntah, rasa penuh, atau cepat kenyang dan sendawa.

3. Siswa Remaja :Orang yang terdaftar di Madrasah Aliyah Negeri Model Manado. peserta didik kelas 3 yang mempunyai hak dalam mengikuti kegiatan belajar disekolah tersebut.

4. Pola Makan : Cara atau perilaku yang ditempuh seseorang atau sekelompok orang dalam memilih,menggunakan bahan makanan dalam konsumsi pangan setiap hari yang meliputi jenis makanan (makanan pedas, makanan asam, 
makanan berlemak, makanan lunak dan keras),serta frekuensi makan (1 kali/hari, $2 \mathrm{kali} / \mathrm{hari}, 3 \mathrm{kali} / \mathrm{hari}$, dan $4 \mathrm{kali} / \mathrm{hari}$ ) yang berdasarkan pada faktor-faktor sosial,budaya dimana mereka hidup.

\section{Cara Pengumpulan Data}

Melalui observasi langsung untuk mendapatkan data tentang lingkungan fisik sekolah. Dan menggunakan kuisioner yang dibagikan dalam kelas dan langsung diisi oleh responden.

\section{Pengolahan Dan Analisa Data}

1. Data Primer

2. Data Sekunder

\begin{tabular}{|c|c|c|c|c|c|c|}
\hline \multirow{3}{*}{$\begin{array}{l}\text { HASIL } \\
\text { PENE } \\
\text { LITIA }\end{array}$} & & \multicolumn{2}{|c|}{ Dispepsia (+) } & \multicolumn{2}{|c|}{ Dispepsia (-) } & Total \\
\hline & Usia (tahun) & $\mathrm{n}$ & $\%$ & $\mathrm{n}$ & $\%$ & \multirow{3}{*}{$\begin{array}{l}60 \% \\
40 \%\end{array}$} \\
\hline & 16 & 30 & $60 \%$ & 0 & $0 \%$ & \\
\hline \multirow{4}{*}{$\begin{array}{l}\text { N DAN } \\
\text { PEMB } \\
\text { AHAS } \\
\text { AN }\end{array}$} & 17 & 18 & $36 \%$ & 2 & $4 \%$ & \\
\hline & Jenis kelamin & $\mathrm{n}$ & $\%$ & $\mathrm{n}$ & $\%$ & \\
\hline & Perempuan & 38 & $76 \%$ & 2 & $4 \%$ & $80 \%$ \\
\hline & Laki- laki & 10 & $20 \%$ & 0 & $0 \%$ & $20 \%$ \\
\hline
\end{tabular}

karakt eristik respon den

Tabel 1.

Distribu

si

sampel

berdasa

rkan

umur, jenis kelamin,IMT dan tempat tinggal dengan kejadian sindroma dispepsia. 


\begin{tabular}{|l|ll|ll|l|}
\hline IMT & $\mathrm{n}$ & $\%$ & $\mathrm{n}$ & $\%$ & \\
\hline $18,5-25$ & 22 & $44 \%$ & 2 & $4 \%$ & $48 \%$ \\
$<18$ & 23 & $46 \%$ & 0 & $0 \%$ & $46 \%$ \\
$>25$ & 3 & $6 \%$ & 0 & $0 \%$ & $6 \%$ \\
& & & & & \\
& & & & & \\
\hline Tempat tinggal & $\mathrm{n}$ & $\%$ & $\mathrm{n}$ & $\%$ & \\
\hline Orang tua & 30 & $60 \%$ & 2 & $4 \%$ & $64 \%$ \\
Saudara/kerabat & 5 & $10 \%$ & 0 & $0 \%$ & $10 \%$ \\
Asrama & 8 & $16 \%$ & 0 & $0 \%$ & $16 \%$ \\
kost & 5 & $10 \%$ & 0 & $0 \%$ & $10 \%$ \\
\hline
\end{tabular}

\begin{tabular}{|l|lc|lc|l|}
\hline & \multicolumn{2}{|c|}{ Dispepsia (+) } & \multicolumn{2}{|c|}{ Dispepsia (-) } & Total \\
\hline $\begin{array}{l}\text { Frekuensi makan } \\
\text { (kali/hari) }\end{array}$ & $\mathrm{n}$ & $\%$ & $\mathrm{n}$ & $\%$ & \\
\hline 1 & 2 & $4 \%$ & 0 & $0 \%$ & $4 \%$ \\
2 & 24 & $48 \%$ & 0 & $0 \%$ & $48 \%$ \\
3 & 21 & $42 \%$ & 2 & $4 \%$ & $46 \%$ \\
\hline
\end{tabular}

aTabel 2. Distribusi sampel berdasarkan keluhan dispepsia.

\begin{tabular}{lcc}
\hline Keluhan & Jumlah(orang) & Persentase(\%) \\
\hline Mual & 23 & $46 \%$ \\
Muntah & 14 & $28 \%$ \\
Nyeri epigastrium & 40 & $80 \%$ \\
Kembung & 16 & $32 \%$ \\
\hline
\end{tabular}




\begin{tabular}{|l|ll|lc|l|}
\hline 4 & 1 & $2 \%$ & 0 & $0 \%$ & $2 \%$ \\
\hline $\begin{array}{l}\text { Konsumsi makanan } \\
\text { tambahan }\end{array}$ & $\mathrm{n}$ & $\%$ & $\mathrm{n}$ & $\%$ & \\
\hline $\begin{array}{l}\text { Rutin setiap hari } \\
\text { Kadang-kadang }\end{array}$ & 13 & $26 \%$ & 0 & $0 \%$ & $26 \%$ \\
Hanya bila ada kegiatan & 9 & $52 \%$ & 2 & $4 \%$ & $56 \%$ \\
Tidak pernah & 0 & $18 \%$ & 0 & $0 \%$ & $18 \%$ \\
\hline Jenis makanan & $\mathrm{n}$ & $\% \%$ & 0 & $0 \%$ & $0 \%$ \\
\hline Makanan pedas & & & & & \\
Makanan asam & 35 & $70 \%$ & 2 & $4 \%$ & $74 \%$ \\
Makanan berlemak & 7 & $12 \%$ & 0 & $0 \%$ & $12 \%$ \\
Makanan lunak dan & 0 & $14 \%$ & 0 & $0 \%$ & $14 \%$ \\
keras & & $0 \%$ & 0 & $0 \%$ & $0 \%$ \\
\hline Kebiasaan & & & & & \\
\hline Alkohol & $\mathrm{n}$ & $\%$ & $\mathrm{n}$ & $\%$ & \\
Merokok & 3 & $6 \%$ & 0 & $0 \%$ & $6 \%$ \\
Olahraga & 4 & $8 \%$ & 0 & $0 \%$ & $8 \%$ \\
Konsumsi obat(aspirin) & 10 & $20 \%$ & 1 & $2 \%$ & $22 \%$ \\
& 4 & $8 \%$ & 0 & $0 \%$ & $8 \%$ \\
\hline
\end{tabular}

\section{Gambaran pola makan}

Tabel 3.Distribusi sampel berdasarkan frekuansi makan, konsumsi makanan tambahan, jenis makanan, dan kebiasaan dengan kejadian sindroma dispepsia. 


\section{a. Kejadian sindroma dispepsia}

\section{1) Angka kejadian sindroma dispepsia}

Dari penentuan awal diagnosis awal dispepsia dengan menggunakan Rome Criteria III, didapatkan angka kejadian dispepsia sebagai berikut :

Tabel 4. Distribusi sampel berdasarkan kejadian sindroma dispepsia

\begin{tabular}{lcc}
\hline Kejadian sindroma dispepsia & Jumlah(orang) & Persentase(\%) \\
\hline Dispepsia & 48 & $96 \%$ \\
Tidak dispepsia & 2 & $4 \%$ \\
\hline Total & 50 & $100 \%$ \\
\hline
\end{tabular}

\section{A. Pembahasan}

\section{Pola makan}

Dari hasil penelitian didapatkan responden memiliki pola makan yang tidak teratur hal ini didasarkan pada frekuensi makan sehari - hari, dimana responden sebagaian besar menjawab mereka makan sebanyak 2 kali dalam sehari sebanyak 48\% ( tabel 3 ). Dan responden juga menjawab konsumsi makanan tambahan yang kadang - kadang juga menunjukkan sindroma dispepsia sebesar $52 \%$. Hal ini sudah menunjukkan bahwa responden memiliki ketidakteraturan makan.

Penyebab dari pola makan yang tidak teratur umumnya bermacam macam. Salah satu penyebab yang paling sering adalah perubahan pola makan pada 
remaja putri.. Selain itu juga terdapat indeks massa tubuh yang kurang dari 18 memiliki angka kejadian sindroma dispepsia yang tinggi sebesar 46\% (tabel 1).

\section{Kejadian Sindroma Dispepsia}

Dari hasil penelitian, didapatkan angka kejadian sindroma dispepsia sebesar 96\% di Madrasah Aliyah Negeri Model Manado ( tabel 4).dan hanya 4\% yang tidak mengalami dispepsia.Dengan kejadian yang paling banyak pada umur 16 tahun sebanyak 60\%. Hal ini juga didukung karena adanya sebagian besar remaja yang telah terdiagnosa oleh dokter dengan sindroma dispepsia sebesar $96 \%$. Angka ini tergolong cukup besar, dan dapat dikatakan bahwa hampir sebagian besar remaja di Madrasah Aliyah Negeri Model Manado mengalami sindroma dispepsia. Berdasarkan penelitian yang lain yang di lakukan pada remaja ditemukan menderita dispepsia sebanyak $27 \%{ }^{6}$

Dari data penelitian ini, dapat di ketahui bahwa sindroma dispepsia memiliki variasi, dan memiliki jenis - jenis keluhan, yaitu mual,muntah,nyeri epigastrium, dan kembung. Hal ini sesuai dengan pernyataan pada buku ilmu penyakit dalam yang menyatakan bahwa sindroma dispepsia adalah keluhan atau kumpulan gejala yang terdiri dari nyeri atau rasa tidak nyaman di epigastrium, mual, kembung, muntah, sendawa, regurgitasi dan rasa panas yang menjalar di dada, rasa cepat kenyang atau rasa penuh, dimana keluhan ini sangat bervariasi, baik dalam jenis gejala maupun intesitas gejala tersebut.

Berdasarkan pada penelitian (tabel 2) ditemukan jenis keluhan terbanyak yakni nyeri epigastrium sebanyak $80 \%$, dan keluhan yang paling sedikit adalah sendawa sebanyak $24 \%$. Variasi keluhan ini serupa juga didapatkan pada penelitian Ervianti(2008), dimana didapatkan sekitar $88 \%$ keluhan nyeri epigastrium sebagai keluhan yang terbanyak, dan muntah sebagai keluhan yang paling sedikiy yakni $40 \%$, dan terdapat penelitian lain yang dilakukan Annisa(2009), didapatkan jenis keluhan terbanyak yaitu nyeri epigastrium sebanyak $50,1 \%$ dan muntah adalah keluhan yang paling sedikit sebanyak $6,8 \% .^{12}$

\section{Hubungan Pola Makan dengan Sindroma Dispepsia}

Berdasarkan hasil analisis penelitian yang dilakukan, didapatkan adanya hubungan antara pola makan yang tidak teratur dengan sindroma dispepsia. Hasil penelitian ini juga didukung oleh hasil penelitian tentang gejala gastrointestinal yang dilakukan oleh Reshetnikov(2007) kepada 1562 orang dewasa, frekuensi makan yang tidak teratur berkaitan dengan gejala sindroma dispepsia. Dan berdasarkan penelitian lain yang dilakukan oleh ervianti (2008) pada 48 orang tentang faktor yang berhubungan dengan kejadian sindroma dispepsia, didapatkan salah satu faktor yang berhubungan dengan kejadian sindroma dispepsia adalah keteraturan makan.

Salah satu faktor yang berperan pada kejadian sindroma dispepsia diantaranya adalah pola makan ${ }^{5}$. Selain jenis - jenis makanan yang di konsumsi oleh remaja, pola makan yang tidak teratur seperti jadwal makan yang tidak sesuai serta kebiasaan yang dilakukan dapat berpengaruh sehingga dapat menyebabkan sindroma dispepsia. Hal ini dapat dilihat dari data penelitian frekuensi makan yang tidak teratur 2 kali dalam sehari $48 \%$ serta konsumsi jenis - jenis makanan yang pedas sebanyak $70 \%$ dan kebiasaan yang kurang baik adalah olahraga dengan perut yang kosong sebanyak 20\% remaja di Madrasah Aliyah Negeri Model Manado yang menunjukkan pola makan yang tidak teratur. 
Selain faktor makanan, salah satu penyebab terjadinya sindroma dispepsia adalah sekresi cairan asam lambung ${ }^{5}$. Asam lambung adalah cairan yang dihasilkan lambung dan bersifat iritatif dengan fungsi utama untuk pencernaan dan membunuh kuman yang masuk bersama makanan ${ }^{7}$. Beberapa bahan makanan tertentu yang bersifat iritatif dapat secara khusus sangat merusak sawar mukosa pelindung lambung yaitu terhadap kelenjar mukus dan terhadap taut epitel yang rapat (tight epithelial junctions) di antara sel pelapis lambung, dua bahan makanan yang paling umum adalah alkohol atau aspirin yang berlebihan ${ }^{8}$. Hal ini akan menyebabkan terjadinya sindroma dispepsia.

Produksi asam lambung berlangsung terus - menerus sepanjang hari . Pengaturan sekresi lambung terdapat beberapa fase termasuk fase sefalik yang dimulai bahkan sebelum makanan masuk ke lambung yang berasal dari korteks serebri yang kemudian dihantar oleh nervus vagus ke lambung yang mengakibatkan kelenjar gastrik terangsang untuk menyekresi HCL, pepsinogen, dan menambah mukus. Hal ini menghasilkan sekitar 10\% dari sekresi lambung normal yang berhubungan dengan makanan. ${ }^{9}$

Frekuensi makan yang tidak sesuai mengakibatkan jeda waktu makan yang lama sehingga produksi asam lambung yang berlebihan dapat mengakibatkan terjadinya sindroma dispepsia.Hal ini sesuai dengan penelitian, dimana frekuensi makan 2 kali dalam sehari dan sebagian responden makan tidak teratur, atau hanya makan 1 kali dalam sehari sebanyak $4 \%$.

\section{PENUTUP}

\section{A. Kesimpulan}

1. Berdasarkan usia yang lebih banyak mengalami dispepsia ditemukan pada usia 16 tahun.

2. Pada remaja perempuan yang paling banyak terkena dispepsia

3. Indeks massa tubuh yang kurang dari 18 memiliki angka kejadian dispepsia yang cukup banyak pada remaja.

4. Remaja yang tinggal dengan orang tua lebih banyak terkena dispepsia

5. Frekuensi makan yang paling banyak pada remaja adalah makan 2 kali dalam sehari.

6. Jenis makanan yang paling banyak dikonsumsi sampel adalah makanan yang pedas.

7. Dispepsia paling banyak di temukan pada remaja yang memiliki kebiasaan olahraga.

8. Persentase kejadian sindroma dispepsia remaja cukup tinggi, dan gejala yang paling banyak dikeluhkan adalah nyeri epigastrium.

9. Terdapat hubungan positif antara pola makan yang tidak teratur dengan kejadian sindroma dispepsia

\section{B. Saran}

Peneliti menyarankan agar remaja lebih memperhatikan pola makannya dan lebih disiplin dalam mengatur jadwal makan sehari - hari. Pelayanan kesehatan, diharapkan untuk memasukkan siswa siswi Madrasah atau SMA sebagai salah satu target promosi kesehatannya. Kegiatan yang disarankan untuk dilakukan adalah penyuluhan tentang dispepsia dan penyuluhan tentang pola makan

\section{Ucapan Terima Kasih}


Terima kasih kepada pembimbing 1 dr.B.J.Waleleng, SpPD-KGEH dan pembimbing 2 dr.Stella Palar, SpPD-KGH yang telah pembimbing penulis dalam menyelesaikan skripsi ini dan kepada semua teman-teman yang tak sempat disebutkan namanya yang telah banyak membantu penulis sehingga dapat menyelesaikan ini dengan baik.

\section{DAFTAR PUSTAKA}

1. Indriani.Yaktimoro,Amir.Mellova,Mirza.Iskandar.Kebiasaan makan yang berhubungan dengan kesehatan reproduksi remaja putri.Jurnal Gizi dan Pangan, Nopember 2009 4(3): $132-139$.

2. Sarwono.Remaja.2001. (http://jtptunimus-gdl-miftakurni-5199-3-bab2.pdf)

3. Anonym. Mengenali jati diri remaja.2007. (http://www.slideshare.net/road_to_khilafah/aqidah-versi-remaja)

4. Susanti.A.Faktor risikodispepsia padamahasiswa Institut Pertanian Bogor .2001. (http://repository.ipb.ac.id/bitstream/handle/123456789/47332/I11asu_BAB\%20I\%2 OPendahuluan.pdf?sequence $=5$ )

5. Sudoyo.Aru.W,Setiyohadi.Bambang,Alwi.Idrus,K.Marcellus.Simadibrata,Setiati.siti. Ilmu Penyakit Dalam.jilid 1.edisi IV.hal 529.Jakarta:Pusat penerbit Departemen Ilmu Penyakit Dalam Fakultas Kedokteran Universitas Indonesia.2009.

6. Reshetnikov.O.V,Kurilovich.S.A,Denisova.D.V,Zavyalova.L.G,Tereshonok.I.N.200 1.Prevalence of Dyspepsia and Irritable Bowel Syndrome Among Adolescent of Novosibirsk.Institute of internal Medicine Russia.Int.J Circumpolar Health 60(2):253. (http://www.ncbi.nlm.nih.gov/pubmed/11507978.).

7. Ervianti.M.2008.Faktor Yang Berhubungan dengan Kejadian Sindroma Dispepsia pada Supir Truk:Studi di PT.Varia Usaha. (http:adln.lib.unair.ac.id/go.php?id=gdlhub-gdl-sl-2008-erviantime-8434.).

8. Reshetnikov.O.V,Kurilovich.S.A.2007.Population-Based Study:Mode of Dieting and Dyspepsia.Pubmed 76(4):35. (http://www.ncbi.nlm.nih.gov/pubmed/17802773).

9. Redaksi.Mengatasi Gangguan Penyakit Maag.Yogyakarta:Banyu Media,25-26.2009

10. Guyton.Arthur.C,Hall.John.E.Buku Ajar Fisiologi Kedokteran.edisi 11.hal.861.Jakarta:EGC.2007.

11. Price.Sylvia.A,Wilson.Lorraine.M.Patofisiologi Konsep Klinis Proses-proses Penyakit.Vol.1.Edisi 6.hal.419.Jakarta:EGC.2005.

12. Annisa.2009.Hubungan Ketidakteraturan Makan dengan Sindroma Dispepsia Remaja Perempuan di SMA Plus Al-Azhar Medan. 